\title{
Women and the Da'wah Movement: Historical Analysis of the Khadijah RA's Role in the Time of Rasulullah Saw
}

\author{
Agus Riyadi ${ }^{*}$, Saerozi $^{2} \&$ Fania Mutiara Savitri ${ }^{3}$ \\ ${ }^{123}$ UIN Walisongo Semarang, Indonesia \\ *agus.riyadi@walisongo.ac.id
}

\begin{abstract}
This study aims to provide an overview of the ideal woman's figure as a busband's companion in carrying out da'wah activities. Specifically, the research is directed to explore the historical roots of Khadijah RA's role in the da'wah activities of the Prophet Mubammad. The research was conducted with a qualitative approach through history and literature studies. The results showed that the role of Khadijab $\mathrm{R} A$ in the da'wah of the Prophet Mubammad was carried out in two forms. Spiritually, Khadijah RA strengthened the belief and mentality of the Prophet Muhammad in receiving and spreading the message of Islam. Materially, Khadijah strengthened the da'wah of the Prophet by building trade relations and marital ties, elevating the living conditions of the Prophet Muhammad's welfare, and appearing to play a role both with energy, mind, and wealth. This research has implications for efforts to build commitment, consistency, and collaboration of women's da'wah. Moreover, it is useful to respond global challenges and strengthen Islamic da'wah activity in Indonesia for personal, family, and institutional scopes.
\end{abstract}

Keywords: contribution; Islamic da'wah; Khadijah $\mathrm{R} A$.

\begin{abstract}
ABSTRAK
Penelitian ini menggambarkan figur seorang wanita ideal sebagai pendamping suami dalam melaksanakan kegiatan dakwah. Secara spesifik, penelitian diarahkan dengan menggali akar historis peran Khadijah RA dalam kegiatan dakwah Rasulullah Saw. Penelitian dilakukan dengan pendekatan kualitatif melalui studi historis dan kepustakaan. Hasil penelitian menunjukkan bahwa peran Khadijah RA dalam dakwah Rasulullah Saw dilakukan dalam dua bentuk. Secara spiritual, Khadijah RA memperkuat keyakinan dan mentalitas Rasulullah Saw dalam menerima dan menyebarkan risalah Islam. Secara material, Khadijah memperkuat dakwah Rasulullah dengan cara membangun hubungan dagang dan ikatan perkawinan, mengangkat kondisi kesejahteraan nabi Muhammad Saw dan tampil memberikan peranan secara tenaga, pikiran maupun harta kekayaannya. Penelitian ini berimplikasi terhadap upaya membangun komitmen, konsistensi dan kolaborasi dakwah perempuan dalam memperkuat aktivisme dakwah Islam di Indonesia baik dalam ruang lingkup personal, keluarga dan kelembagaan.
\end{abstract}

Kata kunci: kontribusi perempuan; dakwah Islam; Khadijah RA.

Received: Januari 2021. Accepted: Maret 2021. Published: Juni 2021 


\section{INTRODUCTION}

The involvement of women in Islamic da'wah activities has existed since the time of the prophet Muhammad SAW sent by Allah as a prophet and apostle, to the peak of belief about his apostolic mission, the first person who converted to Islam was his loyal and beloved wife, Khadijah RA (Arnold, 1985:10). Outwardly Khadijah RA has allowed the prophet Muhammad SAW to live on a social level as he deserves. More than that, as a wife Khadijah RA has put sincere love and loyalty and provided moral encouragement with sympathy when the Prophet Muhammad experienced mental turmoil.

Khadijah RA has a noble personality and noble character. In her daily life, Khadijah RA always maintains her chastity and dignity from the bad habits of the jahiliyah people such as worshiping idols and killing baby girls due to shame and fear of poverty. Khadijah has perfect reputation, thats why she awarded a predicate "Ath-Thahirah" (The Holy One) (Razwy, 1993: 22). This predicate was an extraordinary award because it was given by fellow Arabs who were famous for their arrogance and men pride at that time.

As a wife, Khadijah RA is very familiar with her husband's personality and moral who does not like the bad behavior of jahiliyah society which is astray from the truth. This understanding attitude is manifested by allowing her husband to enter a thinking life to seek the essence of truth. When her husband stays alone or persists in the Cave of Hira ', he provides provisions to stay for several days in search of the true essence. When the Prophet Muhammad was in anxiety and confusion after receiving the first revelation, Khadijah $\mathrm{RA}$ always entertained and convinced that her husband would be an apostle who would elevate his people from humiliation and misguided into a glorious and ultimate truth. Khadijah RA's attitude shows how much a wife's love for prophet Muhammad Saw that is based on tough faith.

Khadijah RA as a person who first believed in the Prophet Muhammad that had given an important role in the early periods of Islam. When the Prophet Muhammad began to broadcast Islam to his people, he often received cynical responses, ridicule, pressure, and threats that endanger his life and his family's safety. At such times, Khadijah RA has helped with many kinds of extraordinary sacrifices. Khadijah RA's role in the great struggle of the Prophet Muhammad has been recognized by him 
as contained in a hadith:

"It is not Allah Azza wa Jalla who gave me a better replacement than her (Khadija), indeed she believed in me when other humans denied me, she justified me when other humans denied me, she helped me with her wealth when other humans did not give, and Allah Almighty gave me the gift of a child from him when other women did not give it (Hambal, tt: 118).

Khadijah RA's determination in the struggle to support the da'wah of Islam in the early days showed a faith solid vision so that Allah Swt gave her a position as an ummul believer. Khadijah RA's position as an ummul believer shows a high level of dignity and a position that demands enormous responsibility. As explained by Abdullah Yusuf Ali in his explanation of Surah al-Ahzab (6) as follows:

This surah shows the dignity and position of the wives of the Prophet Muhammad, who have special responsibilities as mothers of believers. They should not be like ordinary women: they must give guidance to women in carrying out religious orders, visit the sick or the afflicted, and do other good things to help the prophet's mission (Ali, 1992: 1057).

The love relationship between Rasulullah Saw and Khadijah RA is indeed very harmonious because it is based on trust and mutual understanding. The purpose of his household is not wealth, he has sacrificed his wealth in the way of Allah, it is not reputation also because everything has faded since he was ridiculed and insulted by the Quraish people. Thus, there are factors play a role in the Prophet Muhammad life until he has the obstinacy, courage, and strength in the struggle uphold Islam into the great success. Michael Hart said that:

He is the prophet Muhammad Saw, the only human in history who has succeeded in obtaining extraordinary successes both in terms of religion and worldly scope. Coming from a humble family, Muhammad Saw established and propagated one of the world's largest religions, Islam (Hart, 1986: 27).

Apart from Allah's destiny which has determined the success of the Prophet's da'wah, it appears that Khadijah RA as his wife has shown a very large role. But how did Khadijah RA contribute to the success of the Prophet's da'wah, both in spiritual and material forms? 'This is the problem background how importance studying further about Khadijah RA in her contribution to the success of the Prophet's da'wah. 
The role of women in da'wah is an integral part of realizing national development, it means that efforts to align women and men become something that is no longer taboo so that gender equality will be realized in various fields of life. Many research is related to the women contribution in da'wah and development. Some of these results include research conducted by Hasanah (2018: 250) which states that da'wah activities do not have to be carried out by men only, but women can also take part in carrying out da'wah. They must pay attention to their parts that can be done by women when implementing da'wah activity. Research conducted by Rizha (2020: 37) shows that women in the Gayo highlands carry out da'wah activities by holding recitations held once a week, religious counseling, reading and writing Qur'an education, coaching and empowering the community's economy. This is can be done by women without the men involvement.

The results of similar research conducted by Ufiana (2016: 86) also confirm that the contribution of women in da'wah activities can be done through one of the religious organizations. This can be seen in the Muslimat NU activities in Jepara Regency which has a fairly large role development in Nyamuk Village, Karimunjawa District. The da'wah activities who carried out by Muslimat NU can increase women's religion understanding and social society, in-depth knowledge and Islamic understanding teachings, as well as the educational institutions establishment, namely TK and TPQ in Nyamuk Village.

Rohana's research (2018) examines the contribution of women's da'wah in the Aisyiyah Islamic organization in Makassar. It was concluded that the optimization of women's da'wah can be used as a role model in building Islamic civilization, especially through family resilience. Women have a high ethos and optimism in narrating Islamic messages that are oriented towards community transformation. Nurmahyati (2016) also explores the paradigm of da'wah based on women's empowerment. It was found that the contribution of women's da'wah is oriented towards the awareness and religious activities for the worldly life welfare and the hereafter.

This contribution includes daily spaces related to the society welfare. As emphasized by Sholehah (2018) through his research which recorded the contribution of women in agriculture-based da'wah in rural areas. It is concluded that the women's da'wah movement in agricultural development in rural areas has implications for household welfare. It strengthens the role 
of women as the womb of civilization who does not only take care of domestic affairs but also plays a role in the public sphere based on the people's interests.

The women's da'wah movement on contemporary issues needs attention. For example, Nurbayan's research (2017) explores the reconstruction of women's da'wah on campus. The campus as an academic space and movement activism cannot be separated from the role of women in Islamic da'wah. This research shows that the cadre of women da'wah activists on campus is significant in the transmitting process and transforming Islamic values. In the political space, women have a role in the political da'wah implementation. Hasanah's research (2018) shows that the women involvement in the political field shows a parallel contribution towards integrative awareness in national development. Men and women have their work areas and networks to actualize Islamic teachings in the strategic spaces of the state.

Another research conducted by Rohma (2019) relates to the women's da'wah movement in fighting terrorism. This research takes a case study on the female student da'wah organization, IPPNU in Lamongan. The results show that there are four da'wah strategies against terrorism. First, by grounding aswaja as the basis for Islam, maintaining the shalawatan tradition, empowering women based on women's figh, and developing daiyyah as agents of change.

This research is historical research and literature (library research). Literature research requires more philosophical and theoretical preparation than qualitative field empirical tests, which have the intention of being a type of research whose findings are not obtained through statistical procedures or other calculation forms (Muhadjir, 1996: 26; Creswell, 198: 37). The approach used is historical which aims to find out the Khadijah RA's history and contribution in helping the success of the prophet Muhammad Saw da'wah. Khadijah was used as the research object to observe her work in contributing to the da'wah of the prophet Muhammad Saw.

Data collection techniques are: 1) library research (library research), where the data used is library data (Achmadi, 2010: 46). Researchers try to explore references related to the title of the study and then mix them with existing references or have a common theme. 2). Documentation, is a data collection instrument that is often used in various data collection methods (Kriyantono, 2010: 120). Researchers explore historical documentation that 
elaborates on the contribution of Khadijah RA to the da'wah success of the prophet Muhammad Saw. It also explore supporting data about the existence of Khadijah RA as the prophet wife, it is expected to be able to provide information about how a wife should support her husband.

\section{RESULTS AND DISCUSSION}

\section{Genealogy and Personality of Khadijah RA}

Khadijah was born in Mecca around the year 556 AD. Regarding the birth of Khadijah RA, there is no data explains exactly, the estimated year of birth is based on the time of marriage fact to the Prophet Muhammad was about 40 years old, while the Prophet Muhammad was 25 years old. It shows that Khadijah RA is 15 years older than the Prophet Muhammad. Thus, if the Prophet Muhammad was born in 571 AD, then Khadijah RA is estimated to be born in $556 \mathrm{AD}$.

Khadijah RA is the daughter of Khuwailid bin Asad bin Abdul Uzza bin Qusai. Qusai is a descendant of the Bani Hashim, that lineage the Prophet Muhammad was born. Meanwhile, Khadijah RA's mother was Fatimah, daughter of Zaidah, who also came from the Quraysh people. Thus, Khadijah RA was born to a father and mother whom both came from the Quraish people, the most famous one in the entire Arabian Peninsula. The Quraysh people is very well known throughout the Arabian Peninsula because it guards the Baitullah and also holds the affairs of the Hajj (Wafiyah, 1983: 19). The genealogy of Khadijah RA in the Quraysh tribe and the relationship between her lineage and the Prophet Muhammad can be described as follows: 


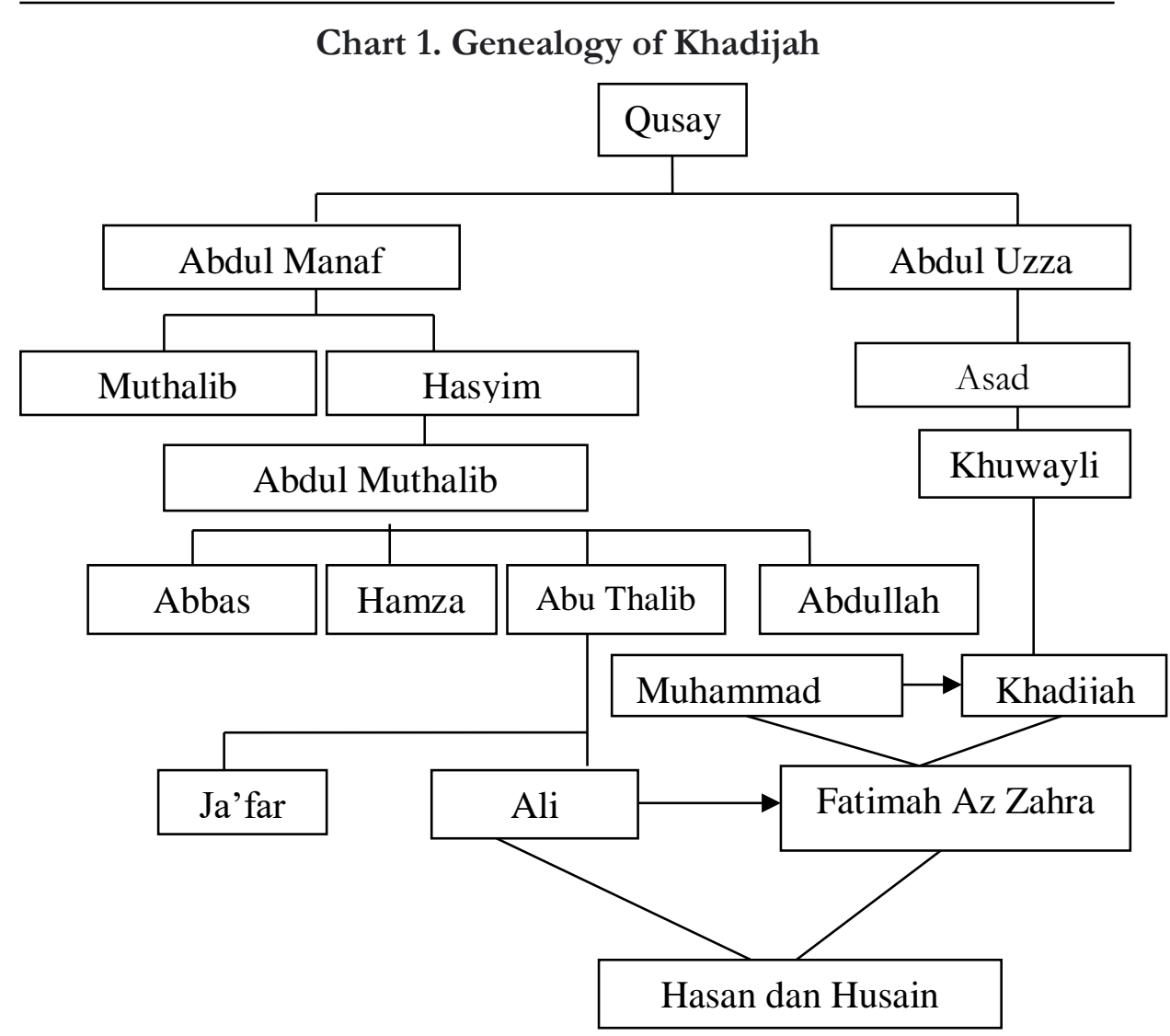

As the Quraysh member in general, Khadijah's father was a merchant. Trade is the main source of livelihood because they do not have fertile land and sufficient water for agriculture. To meet their food needs, they bring it from Syria and Yemen. Through this trading business, they also get profits, so that they can be used to meet other life necessities (Razwy, 1993: 5).

The Quraysh had a traveling habit, especially for trade purposes, the main destination to Syria in the summer and to Yemen in the winter. So was Khuwailid, the father of Khadijah RA. In his business trip, he received security guarantees from the classy people of the countries he passed. This is a blessing given by Allah Swt to Khadijah RA's father to meet the family needs.

When Khadijah RA had reached adulthood, her mother died around 
575 AD. Ten years later, her father also died. After the death of her parents, Khadijah RA inherited her parents' wealth. However, Khadijah RA did not become unemployed and indulged in the inheritance. Armed with a trading tradition as her parents did, Khadijah RA started a trading business. Although Khadijah RA had many brothers, she was the only one who inherited her father's ability to become rich through trading. Then, she proved that even if she did not get the wealth inherited from her father, she would be able to get that wealth with her efforts (Razwy, 1993: 16).

After taking over the responsibility of the family business, Khadijah RA immediately tried to develop it. She has strong managerial skills in controlling her trading business during strong competition. Accompanied by one of her uncles who acted as an advisor, Khadijah RA was able to compete healthily. She also get help from her brother if she needs it one day.

As a wholesaler, Khadijah RA run her business by entrusting her goods to other people to be brought and sold. She gave a proper reward to people who have helped run his business. She also helps people who experience economic difficulties such as the poor, people with disabilities, and gives marriage includes dowries when there are poor girls (Razwy, 1993: 16).

Before Khadijah RA married the Messenger of Allah, she had been married twice. Her first marriage was first with Abu Halal Annabbasy bin Zurarah. From this marriage, she was blessed with a son named Halal. After Abu Halal Annabbasy died, Khadijah RA married for the second time at Atiq bin Abid al-Makhzumi. At the time of her second marriage, her trading business was growing very rapidly. After Atiq bin Abid al-Makhzumi died, she became a respectable widow.

When Khadijah RA became a widow because her second husband died, she attracted the attention of the Quraysh leaders. Many mariage proposals came, but she rejected the proposal in a good way so that it did not offend or feel humiliated for those who proposed to her, the rejection is according to her proposal assessment that they proposed her due to her wealth orientation. Finally Khadijah RA married the Prophet Muhammad until she died in 619 AD.

Khadijah RA is a descendant of the Quraysh people, which is the most famous and respected throughout the Arabian Peninsula. Moreover, because of her managerial skills in carrying out trading business, she was known as a famous wealth woman in Mecca at that time. In fact, it was not 
only her wealth that made Khadijah RA respected by the community, but also because she had noble character and noble personality. In everyday life, Khadijah RA always maintains her chastity and dignity from the bad habits of the jahiliyah people such as worshiping idols and killing their baby girls due to shame and fear of poverty. Khadijah has perfect reputation, thats why she awarded a predicate "Ath-Thahirah" (The Holy One). Khadijah, RA is also known as a person who has a sharp mind, sincere heart, strong wisdom, and high achievements.

Khadijah RA's sharp mind was seen in her ability to try controling her trading business, so she was known as a successful entrepreneur based on social care. The entepreneur who implemented social care to run the business will guarantee its sustainability (Widadi, et al, 2021). The large profits obtained from her trading business are used to help the poor, orphans, and people who need help. It shows that she has a high social sensitivity. Khadijah RA's noble character and personality were also seen when she became the wife of the Prophet Muhammad. Khadijah RA is an ideal woman, both in her role as a wife and housewife to maintain the mandate and responsibilities she receives. Rasulullah Saw once praised Khadijah RA and gave the same position as the noble character of Maryam bint Imran.

\section{Khadijah RA's Contribution Before Muhammad's Apostleship}

Long before Muhammad was sent as an apostle, Khadijah RA was the one who knew him. Not only because Muhammad was known for his honesty, but also they had trade relations. Khadijah RA became more familiar with Muhammad's personality after conducting a marriage bond and starting a family life. Thus, Khadijah RA is a person who has a role in the Muhammad life that cannot be separated from the next period after he was appointed as an apostle. Khadijah RA's contribution before the apostleship is as follows:

First, raise Muhammad Saw from poverty. The journey of Muhammad's life before the apostleship was always filled with suffering and sadness. Before he was born, his father had died so he was born as an orphan. When he was six years old, tragedy struck him again because of the death of Aminah, his mother. His grandfather Abdul Muttalib, who later took care of him, also died before Muhammad reached adulthood. His uncle, Abu Talib took care of him then.

Abu Talib's family lived in poverty. In order to support the family's 
economy, he worked to bring Khadijah RA's goods to be traded to Syria. By Abu Talib, Muhammad was introduced to Khadijah RA. Then Khadijah RA gave the trust to bring her goods to Syria. The profit obtained by Muhammad Saw was very large so his economic situation and Abu Talib family was getting better and more prosperous.

The business path that Khadijah RA gave to Muhammad Saw in overcoming poverty is fact that could awaken his ability to utilize energy and thoughts. The real cause of poverty because of no opportunity to take the potential advantage (energy, mind, and skills possessed). As the definition of poverty according to Soekanto:

"Poverty is defined as a condition in which a person is not able to take care of himself by the standard of living of the group and also the act of being able to utilize the energy, mental and physical possessed by the group" (Soekanto, 1990: 406).

After being given a business path by Khadijah RA, it turned out that Muhammad Saw was able to explore his potential so that he could improve his living conditions from poverty. One of the measuring scales for a person's success is a happy family is the fulfillment of good economic or financial scale, positive interpersonal relationships, and the achievement of life goals together (Cummins, 2018: 19-20). These three scales are called the golden triangle of happiness.

Second, raise Muhammad Saw in a better social status. By the time Muhammad Saw reached adulthood, the desire to marry existed. This can be seen when he accepted Nafisah's offer which conveyed the intentions of Khadijah RA. One thing that is still being considered is that he does not yet have sufficient preparation of assets, even though he already has a business field. When Khadijah RA's proposal came, his problems were resolved to live in a household. He happily accepted the offer, so the marriage held as they wanted.

Muhammad Saw's marriage with Khadijah RA not only brought peace and happiness in their lives but also raised them to a better social status because Khadijah RA was a noble woman who was highly respected among the people and also a rich merchant with a social spirit. His wife's very good repute, made Muhammad Saw increasingly respected by the community, even though he was also known as a person of noble character. In this case, marriage will build a better civilization (Onedera, 2008: 95).

As a wife, Khadijah RA has carried out her obligations perfectly, as well as Muhammad Saw as a husband has tried to balance it. So family's life 
happiness is achieved. The wife's role in family life is very decisive, as Zakiyah Darajat's opinion:

"Women's role as a wife is very important because happiness or misery that occurs in family life is largely determined by the wife. A wise wife can make her household a safe and pleasant place for her husband" (Darajat, 1990: 1).

Khadijah RA has been married twice, before her marriage to Muhammad. The Khadijah RA's age who has matured makes her psychologically mature. That why she can carry out her role as a wife perfectly. Khadijah RA's psychological maturity can be seen from her attitude towards her husband and her independence in various matters. Psychic maturity has a very complex meaning. Psychological maturity implies: having stable emotions, being able to be independent (Zelfstanding = being able to stand on one's own feet, being aware of all responsibilities, having clear goals and directions in life, being productive-creative, and religiously ethical) (Kartono, 1986: 10).

A person's psychic maturity is being able to describe and understand various dynamics in life so that person can integrate bio, psycho, socio, and spiritual aspects well. Psychic maturity is capable of being a powerful force in supporting various activities to be done well (Shek, 1996: 14). Emotional stability, independent attitude, awareness of responsibility, having clear goals and directions in life, productive-creative and religious attitudes have been present in Khadijah RA. Thus, it is very appropriate when Abdul Wahhab Haeasy said: "The role of Khadijah RA in helping her husband is enormous, both in terms of forming a stable character and personality, as well as in thinking patterns" (Hamudah, 1993: 15). Khadijah RA could do this because she already had psychic maturity.

\section{Khadijah RA's Contribution During the Appointment of Muhammad as an Apostle}

Khadijah RA that was very familiar with the Prophet Muhammad personality, have played a role in the aspect of shaping her husband's character, personality, and mindset. Muhammad Saw is known as a person who likes truth and justice. Otherwise, he hates falsehood and cheating. This attitude can be seen from his main attitude, al-amin. Muhammad Saw also hated the jahiliyah people's behavior who were far from the truth such as gambling, drinking, worshiping idols, and so on. This was understood 
by Khadijah RA, so she allowed her husband to to seek the essence of truth.

This attitude of understanding towards her husband can be seen when Muhammad Saw experienced a major event, it is when he received the first revelation of his appointment as an apostle. The role of Khadijah RA for her husband's appointment as an apostle is as follows:

First, remove Muhammad's doubts. After Muhammad Saw received the first revelation in the Hira' Cave, he did not understand what happened to him. The confusion and anxiety also affected his physique. By Khadijah $\mathrm{RA}$, the confusion and anxiety can be immediately calmed through words that encourage her husband with words of praise for his virtues.

Khadijah RA's actions in overcoming the confusion and anxiety of her husband's heart were based on a sense of love and sympathy so that it could foster new hopes in her husband. Sincere sympathy and compassion can help in overcoming difficult life situations, as Kartini Kartono and Jenny Andari argue: "Sympathy and compassion provide peace and assurance of security, and add new hope and a sense of success in every difficult life situation (Kartono, 1986: 256).

Muhammad Saw more convinced of what he experienced that Allah Swt sent revelations to him after getting Waraqah bin Naufal's explanation that Khadijah RA conveyed to him. Khadijah RA's efforts in seeking clarity on this great event helped Muhammad Saw to dispel doubts about revelation.

Second, believe in the apostleship of Muhammad. After the revelation of the first, a moment later the revelation was cut off. At the time, Khadijah RA still allowed her husband to survive in the Hira' Cave. Anxiety and restlessness were experienced again by Muhammad Saw. Khadijah RA as a wife who understands her husband's feelings always provides opportunities for her husband keep staying on spiritual values by contemplating on the eternal nature, so Muhammad Saw has strength and stability in his life. Spiritual values are a way of life that emphasizes optimizing health and well-being which is a manifestation of the integration between body, mind, and spirit within a person (Myers \& Sweeney, 2007: 1). The influence of spiritual values and reflection on the eternal nature of human life. It is emphasized that:

"Spiritual values and reflections on the eternal or divine nature (religious life) can give strength and stability to human life. Because all religious, spiritual and transcendental values that are hidden 
behind or far behind material and worldly values, in essence always contain elements of truth and eternity throughout time" (Kartono, 1986: 257).

In addition, spiritual values will also have a positive impact on one's life, that people who have spiritual and religious competence will have an optimistic attitude, broad knowledge, and capable skills (Vieten, 2013: 135). Spiritual assistance can be a source of developing religious coping strategies for humans in dealing with various kinds of life problems by properly interpreting their religious teachings and also improving their religious rituals (Christian \& Rhodes, 2013: 258-259).

When Muhammad (PBUH) returned from the Hira' Cave before the second revelation came, he experienced anxiety and restlessness which affected his body. Khadijah RA faithfully covered her husband's body, because he seemed to be shivering and seemed immediately to be covered. Khadijah RA's action was intended to eliminate her husband's feelings of anxiety so that happiness would arise again in his heart, as the method of overcoming anxiety according to Zakiyah Darajat:

"There are various ways that can be done to overcome feelings of depression, inner conflict, and anxiety. Such feelings diminish happiness so much that sometimes people are compelled to do something to get rid of the bad feeling. The best way to get rid of the feeling of inner tension is to eliminate the causes (Darajat, 1990: 2829).

After Muhammad Saw received the second revelation as an order to carry out da'wah, Khadijah RA was the first person who believed and welcomed the call for da'wah. Khadijah RA's positive attitude in welcoming the call for da'wah further strengthened Muhammad's heart in taking the next step to carry out his apostolic duties. Her positive attitude in accepting the da'wah showed her steady faith in Allah, because besides that she loved Muhammad Saw, the love of a Muslim to Muhammad Saw is very basic in bearing all the consequences, that:

"A believer who truly believes half-heartedly will love the Prophet who has endured the suffering of the da'wah of Islam, fought with all difficulties so that Islam spread throughout the world, and brought humanity from the darkness of adversity to the light of guidance" (Najati, 1985: 93).

Thus, it is very appropriate if Khadijah RA was later listed as the first woman to believe and embrace Islam, even the first person from all of both 
men and women. That's why Khadijah RA was called the Ummul Believer. On this basis, the contribution of Khadijah RA's da'wah is recorded in the da'wah historical narration of the Prophet Muhammad from before the preprophetic period to the prophetic period (Sarwinda, 2017). Khadijah RA became a role model for the women's da'wah movement that not only provided spiritual support but also material and everything she had for upholding Islam.

\section{Khadijah RA's Contribution to the Prophet's Da'wah}

As it is known that the da'wah at the time of the Prophet Muhammad was divided into two eras, namely the Mecca era and the Medina era. According to a da'wah expert A. Hasymi, the Mecca era is called the period of building the kingdom of God in the human heart, while the Medina era is called the period of fostering the kingdom of God in human society (Hasymi, 1974: 302).

The distribution of the periodization of da'wah carried out by the Prophet Muhammad shows how important the obligation of da'wah is for every individual Muslim to preach anyone (Hares, 2004: 32). The importance of this da'wah of course not only refers to one person, but to all human elements both men and women are obliged to spread Islamic da'wah. As the wife of the prophet Muhammad Saw did.

Khadijah RA accompanied the Prophet Muhammad da'wah activities from the beginning until she died, for approximately ten years, starting with the appointment of Muhammad as an apostle in $610 \mathrm{AD}$ until he died in 619 AD. through the teachings of tauhid. At that time, da'wah activities went through situations. The Prophet Muhammad carried out da'wah through the household, family, confrontation, and power periods because of several Quraysh leader entry into the Muslims.

In the first decade of the Prophet's da'wah activities, he experienced various difficulties with other Muslims. At first, the people did not pay attention to the da'wah, they accused the Prophet of being crazy. However, after the movement of the Prophet Muhammad and the Muslims vehemently opposed the worship of idols and bad habits of society such as gambling, drinking, and so on, it caused anger and reactions of the disbelievers in opposing the preaching of the Prophet Muhammad through persuasion, persecution, and even committing acts of violence. boycott that lasted for approximately three years. In this difficult mission of the Prophet Muhammad, Khadijah RA accompanied him by giving lots of sacrifice. The 
role of Khadijah RA in the da'wah of the Prophet Muhammad in the first decade is as follows:

First, provide spiritual support. When the Messenger of Allah began to proclaim the truth he had received, Khadijah RA was the first to follow that truth. Khadijah RA's faith in Allah and the Messenger encouraged her to support the Prophet Muhammad in carrying out his apostolic duties. Faith in a person has a big influence on personality, which determines the next path of life. As Uthman Najati's opinion is as follows:

Faith in the akidah tauhid itself is the first step in causing major personality changes. Because he, in humans, gives birth to a great spiritual force that changes his understanding of himself, others, life, and the entire universe (Najati, 1985: 304).

Thus, after having strong faith in the creed of monotheism, Khadijah RA had a more stable personality and had great spiritual energy in helping the Prophet's da'wah activities. Because of the encouragement of faith, Khadijah RA in providing support for da'wah never knew despair, even always raised the spirit of the Prophet Muhammad and the Muslims when experiencing difficult situations. Khadijah RA's sincerity in achieving the goals of da'wah is because she has a strong motivation, that comes from her faith in Allah Swt.

The importance of motivation in achieving goals as expressed by psychologist Hubert Bonner in his book Social Psychology, An Interdisciplinary Approach quoted and translated by H.M. Arifin as follows:

Motivation contained a dynamic impulse that underlies all individual human behavior. Whenever there are obstacles that hinder the achievement of the desired goals, with that motivation overcome them and strive to achieve those goals (Arifin, 1991: 48).

It is clear thus that Khadijah RA as a first believer has great spiritual power. This great spiritual power then creates a strong motivation in carrying out da'wah with the Prophet Muhammad to achieve success.

Second, provide material support. It has been acknowledged by historical writers that it is very difficult to reveal the magnitude of Khadijah RA's role in the Prophet's da'wah activities. An expert in da'wah science Toha Yahya Umar revealed the magnitude of Khadijah RA in da'wah activities role as follows:

How great and many services are offered in developing the Islamic da'wah and its defenses to Islam brought by the prophet Muhammad 
SAW. He used all his mind, wisdom and energy, property and body and soul for the benefit of the religion of Islam, so the Apostle once gave him the good news that Allah would give him a palace in heaven (Omar, 1992: 177).

As it is understood that da'wah activities require energy, the mind also requires costs, facilities, and equipment. Likewise, da'wah at the time of the Prophet Saw, was very costly, especially to meet the needs of his followers who experienced difficulties as a result of pressure from the enemies of Islam. Syed A. A Razwy said that Khadijah RA's contribution was as follows:

Since then, everything changed from Khadijah RA. She used all his wealth for Islam. The gift came just in time for Islam. Khadijah RA told her husband that all wealth belongs to the Prophet and can be used as he pleases (Razwy, 1993: 82).

Khadijah RA's generosity in donating all of her belongings for the benefit of da'wah is proof that she provided great support which was needed at that time. Because without financing, a da'wah activity is difficult to achieve its goals. "A business will run smoothly if, in addition to being supported by sufficient and skilled personnel, there are sufficient costs, facilities, and equipment needed. Likewise with the implementation of da'wah. Besides requiring capable and highly dedicated actors, it also requires financing." Khadijah RA's role in the success of the Prophet's da'wah is so perfect, both spiritual and material (Saleh, 1992; 18).

Practically, in the Prophet's da'wah historical narrative, awareness of building a theological mentality both personally and communally becomes the orientation in the enforcing process amar ma'ruf nahi munkar (Rustandi \& Sahidin, 2019). The presence of Khadijah RA had a significant impact on strengthening the foundation of the spread of the message of Islam. Khadijah was the first Quraysh wife and woman who accepted Islam as the womb of civilization, the ummul believers who supported the movement and activism of the Prophet's da'wah. In this case, the role of women as daiyyah will strengthen the character of religiosity and improve the quality of life of the object of da'wah in the vicinity (Sa'diyah, 2008). This is evidenced by the existence of a women's da'wah movement that touches on concrete aspects of community life.

In the contemporary era, this women's da'wah movement is carried out through personal, family, and institutional approaches. The emergence of the new Khadijah in the context of the Islamic da'wah movement 
emphasizes that the obligation of da'wah is a theological as well as sociological obligation that applies to all Muslims with gender, professional, and racial, ethnic, and class differences. In other words, da'wah is the obligation of Muslims to transcend the barriers of difference, aiming to form an ummah community based on spiritual values in responding to various global challenges. The existence of the women's da'wah movement affects the dynamics of the community to transmit and transform the teachings of Islam in the community.

\section{CONCLUSION}

Based on the research discussion, it can be concluded as follows: First, Khadijah RA's contribution in a spiritual to the success of the prophet's da'wah is: Khadijah RA has removed any doubts about what was experienced by the prophet Muhammad Saw, that after the prophet Muhammad Saw received the order to preach. Khadijah RA was the first person who responded to the call for da'wah by declaring his faith and embracing Islam.

Second, the contribution of Khadijah RA in the materials form to the success of the prophet's da'wah is a) Trade relations and marital bond between the prophet Muhammad Saw and Khadijah RA, she has made him lifted from poverty and raised in a better social status, this is because Khadijah RA is a wealthy merchant and has a good reputation among the people; and b) When preaching Islam faced various challenges, Khadijah RA as a wife appeared to give a role with energy, mind and wealth, even though long before her husband was appointed as an apostle, Khadijah RA had also played a role in her husband's life journey.

This research has implications for efforts to build commitment, consistency, and collaboration for women's da'wah to respond the global challenges. This research is expected in strengthening the formulation and strategy of women's da'wah among civilization through word of mouth. The presence of women's Islamic community organizations in Indonesia such as Muslimat NU, Aisyiyah, Persistri, and the others are the foundation to strengthen Islamic da'wah activism in Indonesia. 


\section{REFERENCES}

Achmadi, C. N. (2010). Metode Penelitian. Jakarta: PT Bumi Aksara.

Ali, A. Y. (1992). The Meaning of Holy Qur'an, Amna Coorporation. Maryland USA: Brentwood.

Arifin, M. (1991). Psikologi Dakwah. Jakarta: Bumi Aksara.

Arnold, T. W. (1985). Sejarah Dakwah Islam. terj. H.A. Nawawi Rambe. Jakarta: Widjaya.

Christian, S. C., \& Rhodes, J. E. (2013). "Religious Coping, Posttraumatic Stress, Psychological Distress, and Posttraumatic Growth Among Female Survivors Four Years After Hurricane Katrina", Journal of Traumatic Stress April 2013, vol. 26.

Creswell, J. W. (1998). Quality Inquiry and Research Desighn; (Chosing among Five Traditions. London; Sage Publications.

Cummins, R. A. (2018). "The golden triangle of happiness: Essential resources for a happy family." International Journal of Child, Youth and Family Studies 9.4.

Darajat, Z. (1990). Kesehatan Mental. Jakarta: Haji Masagung.

Darajat, Z. (1990). Isalam dan Peranan Wanita. Jakarta: Bulan Bintang.

Hambal, A. A. I. (t.th). Musnad Al-Imam Ahmad ibn Hambal. Jilid. VI, Beirut: Darul Fikri.

Hamudah, A. W. (1993). Rumantika dan Dinamika Kebidupan Rumah Tangga Rasulullab SAW. terj. Basri Iba Asghary. CV. Akademi Pressindo, cet. I.

Hares, A. (2004). "Keragaman Masyarakat sebagai Objek Dakwah", dalam Jurnal Ilmu Dakwah al-Haḍ̂ahah, Banjarmasin, Vol. 3 No. 6, Juli Desember.

Hart, M. H. (1986). Seratus Tokoh yang Paling Berpengaruh dalam Sejarah, terj. Mahbub Djunaidi. Jakarta : PT. Dunia Pustaka Jaya.

Hasanah, U. (2018). Gender dalam Dakwah Untuk Pembangunan (Potret Keterlibatan Perempuan dalam Politik), Jurnal Ilmu Dakwah, 38(2), 250-266.

https://journal.walisongo.ac.id/index.php/dakwah/article/view/38 $87 / 2166$.

Hasymi, A. (1974). Dustur Dakwah Menurut al-Qur'an. Jakarta: Bulan Bintang.

Hasanah, U. (2016). Perempuan dan Dakwah Kontemporer, Jurnal Reflektika, 12(12), $33-42$. 
https://garuda.ristekbrin.go.id/documents/detail/959100.

Kartono, K. (1986). Psikologi Wanita: Wanita Sebagai Ibu dan Nenek. Bandung: Alumni.

Kriyantono, R. (2010). Teknik Praktis Riset Komunikasi. Jakarta: Kencana.

Muhadjir, N. (1996). Metodologi Penelitian Kualitatif. Yogyakarta: Rake Sarasisn.

Myers, J. E., \& Sweeney, T. J. (2007). Wellness in counseling: An overview (ACAPCD-09). Alexandria, VA: American Counseling Association.

Nurbayan, S. T. (2017). Rekostruksi Gerakan Perempuan menuju Kemenangan Dakwah kampus, JIME, 3(1), 342-353.

Nurmahyati, S. (2016). Dakwah dan Pemberdayaan Perempuan, Jurnal Komunika, 10(1), $169-185$.

https://garuda.ristekbrin.go.id/documents/detail/1406450.

Najati, M. U. (1985). Al-Qur'an dan Ilmu Jiwa, terj. Ahmad Rofi'Usmani. Bandung: Pustaka.

Omar, T. Y. (1992). Ilmu Dakwah. Jakarta: Widjaya Karta.

Onedera, J. D. (2008). The Role of Religion in Marriage and Family Counseling (The Family Therapy and Counseling Series). New York: Routledge.

Razwy, S. A. A. (1993). Khadijah yang Agung : Keteladanan dan Keagungan Seorang Istri, terj. Alwiyah Abdurrahman. Bandung: Mizan.

Rizha, F. (2020). (Perempuan Dan Dakwah di Dataran Tinggi Gayo, Jurnal Peurawi: Media Kajian Komunikasi Islam, 3(1), 37-56. DOI: http://dx.doi.org/10.22373/jp.v3i1.6519.

Rustandi, R., \& Sahidin, S. (2019). Analisis Historis Manajemen Dakwah Rosulullah Saw dalam Piagam Madinah, Tamaddun: Jurnal Sejarah dan Kebudayaan Islam, 7(2), 362-387. DOI : 10.24235/tamaddun.v7i2.5503.

Rohana. (2018). Dakwah Muhammadiyah Melalui Optimalisasi Peran Perempuan dalam Dakwah Aisyiyah (Studi Kasus: Aisyiyah Ranting Kassi-Kassi Cabang Karunrung Kota Makassar), Jurnal Bimas Islam, 11(11), 301-324. https://doi.org/10.37302/jbi.v11i2.55.

Rohma, Z. F. (2019). Perempuan dan Gerakan Dakwah: Upaya IPPNU

Lamongan, Jurnal Dakwah: Media Komunikasi dan Dakwah, 20(2), 1-13. https://garuda.ristekbrin.go.id/documents/detail/2011938.

Sa'diyah, D. (2008). "ISU PEREMPUAN" (Dakwah dan Kepemimpinan Perempuan dalam Kesetaraan Gender), Jurnal Ilmu Dakwah: Acadmic Journal for Homiletic Studies, 4(12), 305-334. 
https://journal.uinsgd.ac.id/index.php/idajhs/article/view/397/40 5.

Saleh, A. (1992). Manajemen Dakwa: Dakwah Pembangunan, DIY: DPD I, Golkar.

Sarwinda. (2017). Dakwah Perempuan Pada Masa Rasulullah Saw, Bina Al'Ummah: Jurnal Ilmu Dakwah dan Pengembangan Komunitas, 12(2), 93110. DOI: https://doi.org/10.24042/bu.v12i2.3290.

Shek, D. T. L. (1996). "Midlife crisis in Chinese men and women." The Journal of psychology 130.1.

Sholehah, M. (2018). Dakwah untuk Pemberdayaan Perempuan dalam Pembangunan Pertanian di Perdesaan, Jurnal Ilmu Dakwah, 38(2), 204-218.

https://journal.walisongo.ac.id/index.php/dakwah/article/view/38 $71 / 2162$.

Soekanto, S. (1990). Sosiologi Suatu Pengantar. Jakarta: Rajawali.

Ufiana. (2016). Efektivitas Dakwah Muslimat Nu Di Desa Nyamuk Kecamatan Karimunjawa Kabupaten Jepara. Jurnal An-Nida, 8(1), 8392. DOI: https://doi.org/10.34001/an.v8i1.766.

Vieten, C. (2013). "Spiritual and Religious Competencies for Psychologists", Psychology of Religion and Spirituality, American Psychological Association. Vol. 5, No. 3.

Wafiyah. (1983). Sejarah Dakwah. Fakultas Dakwah IAIN Walisongo. Semarang.

Widadi, B., Hamid, N., Savitri, F. M., Perwita, A. D., \& Barreto, D. M. (2021). Customer Loyalty Establishment Model based on Corporate Social Responsibility (CSR) Program in Timor Leste. Webology, 18(Special issue on Management and Social Media), 299-321. 